\title{
The Role of the Correctional Hall of Serang in the Settlement of Child Offender Through Diversion in Juvenile Justice System
}

\author{
Nurul Azim \\ Faculty of Law, Universitas Pembangunan Nasional Veteran Jakarta, Indonesia \\ https://doi.org/10.47814/ijssrr.v4i1.60
}

\begin{abstract}
Child imprisonment turns out to not be able to prosper children and interfere with children's growth and development. Children's rights are recognized globally through the Convention on the Rights of the Child through Presidential Decree Number 36 of 1990 concerning Ratification of the Convention on the Rights of the Chilid (Convention on the Rights of the Child). The research method used is normative juridical using a statutory approach and a case approach. How is Bapas' war in resolving children in conflict with the law, through a diversified approach at the stage of investigation, prosecution and examination in court, as well as whether the obstacles in solving children's cases conflict with the law through diversion at the stage of investigation, prosecution and trial in court. The role of Bapas Class II A Serang in Resolving Children in Conflict with the Law through Diversion at the stage of Investigation, Prosecution and Court Examination, is to make Community Research Reports and supervise children in conflict with the law.
\end{abstract}

Keyword: Child Protection; Juvenile Justice System; Diversion

\section{Introduction}

Children are both a mandate and a gift from God Almighty, which we must always protect, because they are inherent in their dignity and human rights which must be upheld. Children as creatures of God Almighty have rights from birth, so that no human or other party can take these rights away.

The state upholds human rights, including the human rights of children, which is marked by the guarantee of protection and fulfillment of children's rights in the 1945 Constitution of the Republic of Indonesia and several statutory provisions, both national and international. This guarantee is strengthened through the ratification of the international convention on children's rights, namely the ratification of the Convention on the Rights of the Child through Presidential Decree No. 36 of 1990 concerning Ratification of the Convention on the Rights of the Chilid (Convention on the Rights of the Child).

Children in conflict with the law are part of society who are helpless physically, mentally and socially so that handling them needs special attention. Children who get good protection create a quality generation, which is needed for the future of the nation. Due to the lack of physical, mental and social maturity, children need special attention and guidance including, including legal protection, both before and 
after birth. All children have the right to special protection and to have the opportunity guaranteed by law and other means to grow and develop, whether physically, mentally and socially.

Protection of children is carried out in aspects of life, including in this case the juvenile criminal justice. Juvenile criminal justice is specifically for children in conflict with the law, namely children who have committed a criminal act. Juvenile Criminal Court upholds the rights of children, both as a suspect, defendant and as a prisoner. The enforcement of the rights stipulated in the laws and regulations on juvenile criminal justice is in the context of realizing child protection. In several incidents that have occurred in decades, there have been various problems or cases related to children dealing with the law, whether children are perpetrators, victims or witnesses.

Protection of children is carried out in aspects of life, including in this case the juvenile criminal justice. Juvenile criminal justice is specifically for children in conflict with the law, namely children who have committed a criminal act. Juvenile Criminal Court upholds the rights of children, both as a suspect, defendant and as a prisoner. Enforcement of the rights stipulated in the laws and regulations on juvenile criminal justice is in the context of realizing child protection.

Along with the development and increasing public awareness of the need for regulations that can provide protection for children who are faced with laws that have not been comprehensively regulated by Law Number 3 of 1997 concerning Children's Courts. So on July 30, 2012 the government together with the DPR ratified Law Number 11 of 2012 concerning the Juvenile Criminal Justice System, which in article 1 point 1 states "The Juvenile Criminal Justice System is the entire process of resolving cases of children who are facing with the guidance stage after serving a sentence. The Criminal Justice System (SPPA) aims to protect the dignity of children. Children have the right to special protection, especially legal protection in the judicial system. Therefore, SPPA is not only emphasized on the imposition of sanctions, it is intended as a means of realizing the welfare of the child perpetrators of the crime. The paradigm shift in the handling of children is related to the law, demanding the participation of the community, government and other state institutions.

Academically, the resolution of legal problems against children in conflict with the law is pursued using a restorative approach or known as restorative justice. The forms of intervention on a violator should not be aimed at punishing or to re-instill the values prevailing in society to the perpetrator of the violation, but to repair or compensate for the losses or suffering caused by the violation that occurred. It is necessary to obtain confirmation of protection in relation to children who are perpetrators of criminal acts, children who are victims of crime and children who are witnesses of criminal acts, because their treatment needs to be differentiated according to their needs.

Prior to the enactment of this law, "naughty" children who were brought to court by the judge were designated as State Children by sending them to Correctional Institutions (LAPAS) and Community Service Centers (BAPAS) apparently did not make children better off. Many of the naughty children repeated the crimes they had committed, even with the quality and quantity of the crime (recidivist) more serious than the child's condition before being coached at LAPAS and mentored at BAPAS. One of the contributing factors is that the children have been contaminated with negative habits in LAPAS. According to Prof. Widodo, SH, MH, the sociological conditions at LAPAS Anak that "force children" to accept the values of crime and get used to bad behavior, which criminologists call prisonization.

Apart from that, imprisoning children apparently cannot prosper the child and disturbs the child's growth and development. Because of that Law no. 11 of 2012 concerning the Juvenile Criminal Justice System (UU-SPPA) contains 2 important concepts, namely Restorative justice and Diversion (counseling) 
which allows children to face the law not to be imprisoned. Article 82 paragraph (1) of the Law on the Criminal Justice System for Children states that actions that can be given to children include a) returning to parents / guardians; b) delivery to someone; c) treatment at a mental hospital, d) treatment at the LPKS; e) the obligation to attend formal education and / or training held by the government or private bodies; $f$ ) revocation of driving license and / or; g) corrections due to criminal acts.

Handling of children in conflict with the law must be based on the best interests of the child, related to the nature of the child, both physical, psychological and social, so that the interests of the children do not have to be the same. Custody of children in conflict with the law does not have to use non-penal means (for example diversion or using criminal law (penal means). However, both can be carried out sequentially, namely using diversion (if diversion meets the requirements of diversion) and if the effort fails, the criminal justice system will be carried out child.

In general, the implementation of the criminal justice system for the settlement of criminal cases can have a negative impact on children, especially the provision of "evil stigma" to children (stigmatization or labeling) and the occurrence of habitual bad habits in LAPAS which are then practiced again by children outside of Child Prison (prisonsasi) even the repetition of a more serious criminal offense. Direct contact with law enforcement officials can be frustrating for children. If the case has been decided by the court, it may become a stigma for the child as a criminal offender. Therefore, experts in the fields of psychology, law, criminal etiology, criminology, education and analogies are always looking for the best way for brothers, victims and the interests of society. Finally, the experts discourse a restorative justice approach as an alternative thought to reduce the weaknesses of retributive punishment theory, prevention theory and combined theory.

Restorative justice is an idea and movement that prioritizes justice in the perspective of the perpetrator and his family, victims and their families, communities and stakeholders in the context of restoring their respective circumstances. Therefore, the concept of restorative justice is one of the unnecessary efforts to keep children away from the criminal justice system. This approach prioritizes criminal settlement outside the criminal court. This approach is not only for children, but also for adults (eg petty theft, light embezzlement, cheating (fraud).

With regard to the concept of restorative justice in criminal cases committed by children, according to article 1 number 6 of Law No.11 of 2012 concerning the Criminal Justice System for Children. The definition of restorative justice is the settlement of criminal cases involving perpetrators, victims, and families. The perpetrator / victim, and other related parties together seek a fair solution by emphasizing restoration to its original state and not retaliation.

Since the issuance of the SPPA Law, at all levels of the criminal justice process (investigation, prosecution, trial in court), there are opportunities for the police, prosecutors and judges to carry out diversions. Thus, in the handling of children in conflict with the law, cases, diversion in cases are carried out by the police, prosecutors and judges in accordance with their authority in a criminal procedure. If the diversion fails, the criminal justice process at each level will be carried out with the culmination being a court decision. Before the police, prosecutors and judges carry out a diversion process, it must be ensured that the requirements for a case that can be subject to diversion meet the objective and subjective requirements as stipulated in Article 7 paragraph (2). Objective requirements, namely that a criminal case to be processed for diversion is a criminal offender who is punishable by imprisonment of less than 7 (seven) years. The subjective requirement is that the child is not a repeat offender. 
With the issuance of Law Number 11 of 2012 concerning the Juvenile Criminal Justice System, the role of the Correctional Center, especially Community Guidance, is not only limited to making reports on the results of social research which are used to expedite the duties of investigators, public prosecutors and judges. However, with the existence of the law on the juvenile justice system, the role of social adviser is one of the important elements in the process of resolving crimes committed or involving children. And in the law on the juvenile criminal justice system, efforts are put forward to prevent children from the criminal justice process (diversion), in all stages, starting from the process of investigation, prosecution and examination in court.

Based on the background described above, the formulation of the problem in this study is, how is Bapas' war in solving children in conflict with the law, through a diversified approach at the stage of investigation, prosecution and examination in court, as well as whether the obstacles in solving children's cases conflict with law through diversion at the stage of investigation, prosecution and examination in court.

\section{Research Method}

The writing method is basically a search method. It's not just carefully observing an object. In a research activity, research methods are needed so that research becomes more focused with the data collected through data searches that are connected to the problems in this study. The research methods used in this research are as follows.

This type of research used by the author in this thesis is a normative-empirical juridical approach to problems in discussing the problem. Reviewing the applicable legal provisions as well as what is happening in reality in society, or in other words, namely a research conducted on the actual situation or real conditions that occur in society with the intention of knowing and finding the facts and data needed, after the data is collected. needed accumulated then leads to problem identification which in turn leads to problem solving. Researchers will carry out a research approach through a statutory approach. The statutory approach is carried out by examining all laws and regulations that are related to legal issues that the author will examine.

\section{Result and Discussion}

\section{Overview of Children in Conflict with the Law}

Every child has a unique personality that has distinctive characteristics, even if children are born as identical twins. Although children can act based on their own feelings, thoughts and wishes, it turns out that the social conditions in which the child is located have a very big influence in shaping a child's character. Good parenting or parenting guidance and patterns are needed from parents, teachers and other adults in the process of child development.

Children in conflict with the law are part of society who are helpless physically, mentally and socially, so that their handling requires special attention. Well protected children create a quality generation, which is needed for the future of the nation. Due to reasons of their physical, mental and social deficiencies, children need special attention and guidance, including legal protection, both before and after birth. Children have the right to have opportunities guaranteed under the law and other means, to grow and develop physically, mentally and socially. 
Protection of children is carried out in all aspects of life, including in this case in juvenile criminal justice. Child criminal justice is sanctioned against children who are in conflict with the law, namely children who have committed a criminal act. Juvenile criminal justice affirms the rights of children, both as a suspect, as a defendant, and as a prisoner. Enforcement of children's rights is regulated in statutory regulations on juvenile criminal justice, which is a manifestation of the protection of children's rights. Children need to be protected from the negative impacts of rapid development, the flow of globalization in the field of communication and information, advances in science and technology, as well as changes in the style and way of life of some parents that have brought about fundamental social changes that greatly affect values and values. child's behavior. Contribution of behavior or illegal acts committed by children, among others, is caused by various factors that are outside of the child.

Data on children who faced the law from the Indonesian Child Protection commission in 2018 that were received by the complaint department recorded 1.434 cases. In general, the cases highlighted by KPAI were dominated by sexual crimes with children as the perpetrator or the victim. Related to the situation of children being perpetrators and dealing with the law, it is caused by various factors.

According to research conducted by KPAI in 15 prisons in Indonesia, the driving factor for crimes committed by children is from promiscuity to the influence of social media. Social media that contains pornographic content accessed by children triggers cases of sexual abuse and rape. Meanwhile, other types of illegal acts committed by children are stealing, physical violence, assault, fighting, and developing into stabbing. With a variety of factors that cause children to commit various crimes, he assessed that handling or how to deal with them must also be done together.

Bapas' role in resolving children in conflict with the law, through a diversified approach at the stage of investigation, prosecution and examination in court.

Criminal acts committed by children in general, the provisions that are violated are the criminal regulations contained in the Criminal Code, so the investigation process is carried out by general investigators, in this case the Police investigators. In line with the enactment of the Law on Juvenile Criminal Justice System (SPPA), it has been confirmed that investigations into cases that are in conflict with the law are carried out by Police investigators on the legal basis of Article 26 paragraph (1) of Law N.11 of 2002 concerning the Child Criminal Justice System In essence, it states that "investigations into child cases are carried out by investigators who are determined based on the Decree of the Chief of Police of the Republic of Indonesia or other officials appointed by the Chief of Police.

Even though the investigators are Polri investigators, not all Polri investigators can carry out investigations into cases of children in conflict with the law. The Law on the Child Criminal Justice System is known to have child investigators, who have the authority to carry out investigations. Child investigators are appointed by the National Police Chief with a special decree. Specifically, for this purpose, the Juvenile Criminal Justice System Law through Article 26 paragraph (3) stipulates the conditions that must be met by an investigator, namely:

a. Has experience as an investigator;

b. Have interest, attention, dedication and understand children's problems

c. Has attended technical training on judiciary 
In the stage of investigating a child in conflict with the law if it meets the requirements for settlement through diversion or diversion from the criminal justice process to an out-of-court process, then in the investigation stage the role of Bapas determines that the child's case can be resolved with an approach outside of formal justice for the best interests of the child.

In the first stage, the education stage as mandated in Chapter III PP N0. 65 of 2015 concerning Procedures and Coordination of the Implementation of Diversion, Article 12 states that within a period of 1 x 24 (one time twenty four) hours from the issuance of an investigation warrant, the investigator submits a notification letter of the commencement of an investigation to the public prosecutor. In carrying out an investigation, the investigator coordinates with the public prosecutor within the same period of 1x 24 (one time twenty four) hours from the commencement of the investigation. In the event of a Diversion effort, the Investigator notifies the Diversion effort to the Public Prosecutor within a maximum period of $1 \times 24$ (one time twenty four) hours from the commencement of the Diversion effort.

Within that period of time from the commencement of the investigation, the investigator will ask the community supervisor to be present to accompany the child and carry out community research, while the professional social worker is asked to make a social report on the victim and / the child of the witness. Both types of reports must have been submitted to the investigator within $3 \times 24$ (three times two times two) hours from the date the investigator's request was received.

Furthermore, within a maximum period of 7 x 24 (seven times two pulum four) hours, starting from the commencement of the investigation, the investigation will notify and offer the child and / or parent / guardian, as well as the victim or child victim to the fund or parent / guardian to resolve it. case through diversion. If both parties agree to undertake a diversion, the investigator will determine a date for the diversion deliberation to begin. The diversion process is carried out within a maximum period of 30 (thirty) days from the date of commencement of diversion and is carried out through deliberation, involving the investigator, the child and / or his / her parents / guardian, the victim or the victim's child and / or his / her parents / guardians, mentors. community, as well as professional social workers.

\section{Reference}

Penjelesan Atas Undang_undang Nomor 35 tahun 2014 tentang Perubahan Atas Undang-Undang Nomor 23 tahun 2002 Tentang Perlindungan Anak.

KPAI, Membangun Indonesia Ramah Anak, Capaian Pelaksanaan Pengawasan Perlinduangan Anak Indonesia 2014-2017 hal 144.

Esthi Susanti dan Yoel Setiawa, Perlindungan Khusus pada Anak: Dialog Pengalaman dengan Teori. Penerbit Aswaja Pressindo hal 249.

Widodo, Diversi dan Keadilan Restoratif Dalam Uu Nomor 11 tahun 2012 tentang Sistem Peradilan Pidana Anak: Menakar Kesiapan Penegak Hukum Masyarakat dan Pemangku Kepentingan hal 252.

Widodo, Prisonisasi Anak Fenomena dan Penaggulanganya Aswaja Pressindo Yogyakarta 2012.

Republik Indonesia, Undang - Undang Nomor 3 tahun 1997 tentang Pengadilan Anak Pasal 34. 
Bambang Sunggono, Metodologi Penelitian Hukum, PT Raja Grafindo Persada, Jakarta, 2007.

Bambang Waluyo, Penelitian Hukum Dalam Praktek, Jakarta, Sinar Grafika,2002.

Kompas. Com. Jernih Melihat Duani. Diakses 7 Agustus 2020 pukul 16.00.

\section{Copyrights}

Copyright for this article is retained by the author(s), with first publication rights granted to the journal.

This is an open-access article distributed under the terms and conditions of the Creative Commons Attribution license (http://creativecommons.org/licenses/by/4.0/). 